\title{
Social Occupational Therapy, Impoverished Youth, and Everyday Urban Mobility
}

\author{
*Monica Villaça Gonçalves. M.Sc. Public Health (Fiocruz); PhD OT. (Federal University of São Carlos - \\ UFSCar). https://orcid.org/0000-0002-8090-9884 \\ Adjunct Professor, Occupational Therapy Department, Federal University of Espírito Santo, Brazil.
}

\author{
Ana Paula Serrata Malfitano. MA Education (Unicamp); PhD in Public Health (USP). \\ https://orcid.org/0000-0002-0502-3 I94 \\ Associate Professor, Occupational Therapy Department, Post-graduate Program in Occupational Therapy, Federal University of São \\ Carlos, Brazil.
}

Considering social participation as an objective in Social Occupational Therapy, we discuss the incorporation of the concept of Everyday Urban Mobility from four of its action technologies: (a) workshops/activities, dynamics and projects; b) individual territorial followups; c) articulation of resources in the social field; d) dynamization of the support network. Based on data from a research study with impoverished young favela ${ }^{a}$ dwellers in Brazil, this study included a secondary analysis of these data, and discusses how urban mobility could be incorporated into social occupational therapy practices. We conclude that social occupational therapy (from a political perspective of mobility), can develop actions to facilitate the urban mobility of young people and use it as a point of departure for occupational therapy professional practice. In doing so, it becomes possible to apply mobility as an objective, a resource, a means of assessing everyday life, and/or an aspect to be considered in micro- and macro-social work endeavours that are linked to social policies.

Key words: Social Occupational Therapy, Youth, Right to Freedom of Movement, Citizenship, Urbanization.

\section{INTRODUCTION}

This study discusses the incorporation of the concept of Everyday Urban Mobility (EUM) into occupational therapy practices and research, specifically in the context of social occupational therapy'. In this paper, EUM refers to the daily movements of people and groups within the urban environment and involves meanings in relation to the sociocultural context, which transform and may be transformed by social relations in cities ${ }^{2-7}$. The restriction or expansion of EUM therefore impacts upon the everyday life spheres of individuals and collectives ${ }^{3}$.

Social occupational therapy is a sub-area of the profession consolidated in Brazil that has been under discussion since the 1970s. The central objective of social occupational therapy intervention is to focus on social question which affect people's everyday lives both individually and collectively, rather than health ${ }^{8}$. It proposes a theoretical-methodological foundation considering citizenship as one of the pivotal points which enables practice?

The concepts of social rights, citizenship, and urban mobility, are integral to Brazilian occupational therapy, and as such, social participation is one of the main objectives of the professional practice of those occupational therapists who practice social occupational therapy $8,10,11$. However, in contexts of greater social vulnerability, such as those which prevail in the Brazilian reality, social participation becomes an elusive and distant possibility for some individuals and collectives. It is therefore reasonable to think that before objectifying social participation in the work of occupational therapists, it may be necessary to consider ways that may be more feasible in the short and medium term. Considering the target population of social occupational therapy, such as young favela ${ }^{a}$ dwellers, their reality shows that, unfortunately, they are far from experiencing effective social participation due to inequality levels. It is for this reason that we approach EUM as a means to assist occupational therapists in finding clues about social participation.

The concept of EUM is one of the possibilities to social occupational therapy interventions, especially for those aimed at communities and territories ${ }^{12}$. In this context, this study was based on the following guiding question: "How can everyday urban mobility be addressed through theoretical and methodological bases in social occupational therapy?" In pursuit of this answer and guided by an understanding of the ethical role played by social research in providing subsidies for professional practices contextualized in local reality, we describe a secondary analysis of the findings of a doctoral research in social occupational therapy principles for actions. Based on this research, we focus on how urban mobility could be addressed in social occupational therapy practices, especially in those conducted with sociably vulnerable young people.

aFavelas are areas comprising popular housing mostly occupied by impoverished workers. Historically, Brazilian favelas are seen as an "urban problem", stigmatized as violent places with no presence of the State that are dominated by criminal factions. Brazilian favela dwellers carry these stigmas, especially the young, who are seen as violent, dangerous, and disorderly ${ }^{21}$. 


\section{Social Occupational Therapy Actions}

According to Gretschel, Ramugondo and Galvaan 13:55, "designing occupational therapy interventions is an essential part of the doing of occupational therapists. The process through which occupational therapists do this is complex, and suitable theories are needed to understand the contextually situated nature of this historically located, collective and socio-culturally mediated activity".

Approaching complex aspects related to unequal realities, based on local knowledge, and focusing on socio-cultural aspects, we were guided by Paulo Freire ${ }^{14}$, who stated in 1978 that "the best way to accomplish those things that are impossible today is to do today whatever is possible"14:100. For Freire, this is not conformity, but the patience required for the praxis to be carried out, based on the critical awareness of those involved ${ }^{14,15}$. This proposition is in line with the social occupational therapy principle to implement contextualized approaches coherent with the concrete possibilities that exist in socio-political and cultural contexts.

In search of methodological action strategies in occupational therapy, we relied on the four social occupational therapy action technologies as presented by Lopes, Malfitano, Silva and Borba ${ }^{16}$ : a) workshops/activities, dynamics and projects; b) individual territorial follow-ups; c) articulation of resources in the social field; and d) dynamization of the support network. In social occupational therapy, the activities are considered as mediators in the intervention process, in which occupational therapists are social articulators.

These activities can occur, amongst others, through workshops. We rely on the definition of Silva ${ }^{17: 213}$, who describes workshops as "spaces consisting of a social group in which proposals associated with doing, with human actions that promote shared learning, are established", that is, places where there is interaction between participants, spaces, materials, memories, sensations, and everything that is being experienced at that moment. Thus, they are "spaces for experimentation and learning in which participants are active in the process, and beings of the praxis, action, and reflection"17:213. Workshops are ways of living in an environment of exchanges that aim to promote experimentation of knowledge and actions and as such, can provide meaningful experiences to their participants.

Individual territorial follow-ups are defined as "intervention strategies that enable real perception of and interaction with the everyday lives and life contexts of people, interconnecting their histories and pathways and their current situations and social networks"16:173. Articulation of resources in the social field and dynamization of the support network are two social technologies that seek to promote actions in the micro- and macro-social spheres ${ }^{16}$. Social policies comprise network actions as part of the resources articulated by the professional, for instance. Access to such resources can result in providing both formal and informal support to people.

\section{METHODS}

\section{Generation of the data}

This paper resulted from a secondary analysis of data from a doctoral thesis in occupational therapy ${ }^{18}$ conducted with young people attending a non-governmental organization (NGO) located in a favela in the city of Rio de Janeiro, Brazil. Its objective was establishing and discussing the EUM of the young people living in that territory and reflecting on the relationships between urban youth mobility and occupational therapy professional practice.

\section{Data Collection}

Data were collected from two projects developed by the University in partnership with the community. In Brazil, these projects are called university extension projects. According to Freire ${ }^{19}$, extension actions aim to propose reflective, dialogical, and transforming actions for all people involved. In Brazil, university extension projects are a statutory function of public universities. They play the role of establishing a relationship of exchange of knowledge between the University and society aiming to articulate academic education and knowledge production based on the plurality of academic and popular knowledge. The policy of all Brazilian public universities to institutionalize university extension projects, guides these institutions in fulfilling their social role by addressing socially relevant demands and problems emerging from the socio-historical-cultural context in which they are situated ${ }^{20}$.

\section{Data Sources}

The two projects included in this study were firstly: "Let's tour the city! Youth, urban mobility, and the right to the city". The first author of this paper was one of the coordinators of this project and personally conducted the activities in that favela together with occupational therapy undergraduate students, students from other undergraduate courses, and academic colleagues and partners in the territory. "Let's tour the city! Youth, urban mobility, and the right to the city", began with the data collection from young people from a favella in 2018. This project aimed at discussing urban mobility and the right to the city and continued after the end of that research.

The second project "Youth: Art-cultural interventions in the territory", aimed at conducting art-cultural workshops with the same young favela dwellers to expand the educational, occupational and social repertoires for education in citizenship and human rights. This project began in 2015 , and the research in question was conducted in 2018 , thus a previous relationship with that territory already existed at that time and continued after the end of data collection.

Our continued involvement throughout the process, not only about research results, but also about actions that may bring about changes for the population with whom we established a relationship during that research, as well as in the university extension project generated a pedagogical concern with respect to the education of occupational therapy undergraduate students and of those from other courses involved in the project.

Data collection occurred between September and December 2018 and was carried out using the following strategies: eight open activity workshops with the participation of two to seven youngsters aged I5-2I years. These workshops were organised as follows (see Table I, p36): one presentation; four workshops on the theme of constructing a "City of Youth" 21 , proposed by the first author of this article when she was conducting the workshops; three reserved for the production of a manga ${ }^{b}$ and one on the theme of Youth and Human Rights as an open event in the favela complex. In addition to the workshops, we individually followed up one female and three

${ }^{\mathrm{b}} \mathrm{A}$ type of Japanese comic book with a child, youth, or adult theme. 


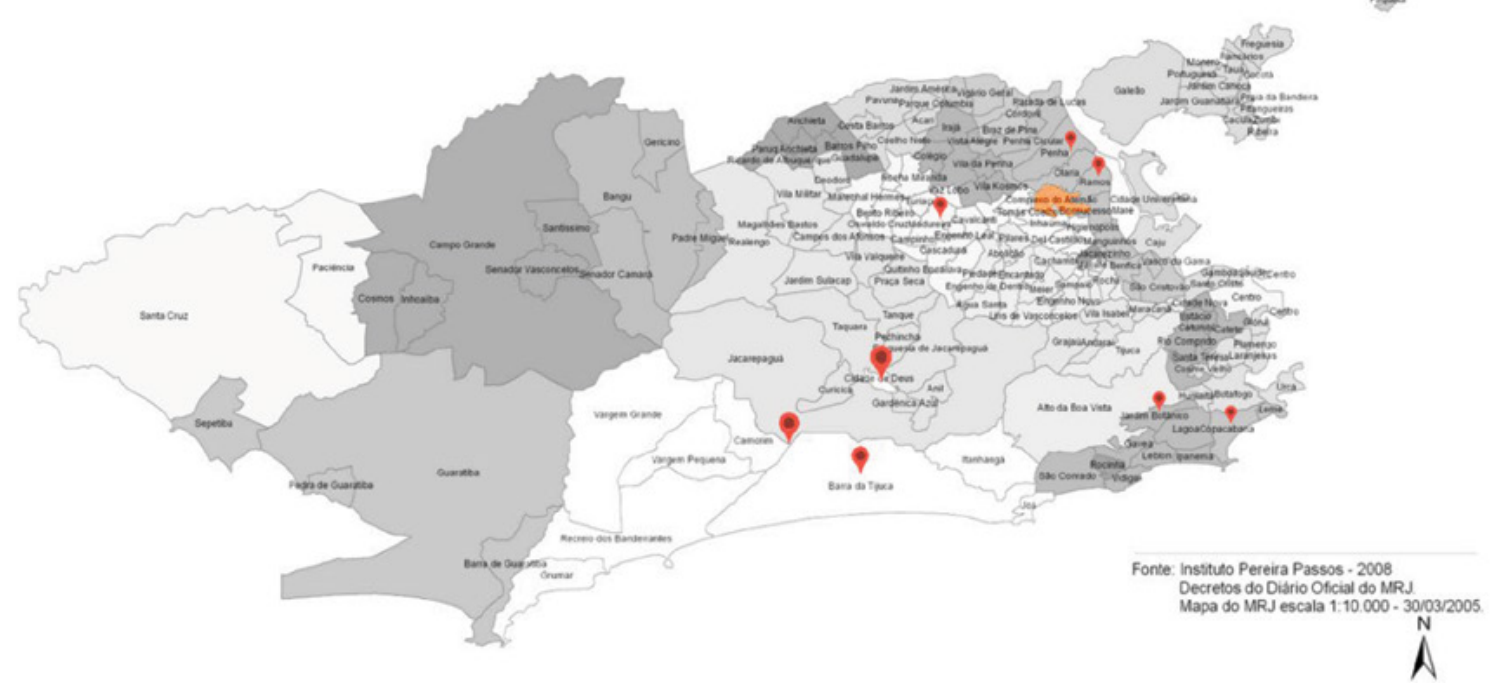

Figure I: Map of the city of Rio de Janeiro, Brazil. The neighbourhood where the youngster lives is marked in orange and the places he visited are marked in red.

male youngsters to understand their narratives about urban mobility. They were invited based on different personal histories of mobility in the favela and in the city. During this phase, we also used activities with visual aids, e.g., maps, fanzines ${ }^{c}$, and photographs, and one of these follow-ups developed into an individual territorial follow-up ${ }^{22}$.

The use of activities (artistic, aesthetic, and cultural) in the research were aimed at discovering the participants' life histories, with a focus on their urban mobility. In Brazil, activities are "traditional" work resources in occupational therapy. In social occupational therapy, local history and culture were taken into account when selecting the activities?.

In addition to being a data collection resource, these activities can be characterized as an organizing axis of interventions in the social field, and are used as resources to mediate "the work of approaching, monitoring, understanding the demands, and strengthening the individuals and collectives they are aimed at"23:282. Specifically aimed at the youth, the activities facilitate approaching and bonding, and are a point of departure for a closer relationship with their target individuals and with the potential of contextualising the dialogue within their everyday life ${ }^{16}$.

Galheigo ${ }^{24}$ pointed out that activities can provide a means of approaching and understanding the everyday life of different people, groups, and/or communities, and assist in understanding the experiences of each individual in their own reality. Thus, we sought to understand the everyday lives of these young people through the activities and their own narratives, as we believed that "talking to young people and listening to their histories in their own voice remains a privileged way of knowing their lives and understanding their lived experiences and subjective realities"25:21.

After completion of data collection for the doctoral research, the university extension projects continued within the same population in the same location. Therefore, because the original research did not focus on occupational therapy actions, a secondary analysis of the results aimed at extracting the practical demands of occupational therapy within that population. This secondary analysis led to a re-examination of the results in search of elements that could support social occupational therapy actions when working with the EUM of young favela dwellers.

Thus, the original research was methodologically based on the dialectical and historical materialism ${ }^{26}$ aimed at a comprehensive analysis ${ }^{27}$ of that reality that sought to respond to the following question: "What is the everyday life of a favela dweller like regarding their mobility through different places in the city?". The secondary analysis, focusing on social occupational therapy actions, was conducted by extracting possibilities of professional practices to produce syntheses aimed at the search for social transformation ${ }^{28-30}$.

In this process, this paper proposes a secondary analysis of data, which is understood here as the re-use of a set of existing data collected by the researchers so that it could be re-analysed from a new perspective ${ }^{3 !}$. In this paper, we added reflections about the applicability of original data in social occupational therapy actions and propose the following guiding question: "How can Everyday Urban Mobility be addressed through theoretical and methodological bases in social occupational therapy?". To this end, we focused on EUM as an objective, an assessment tool, a resource for practice, and a support for the formulation and action with/in public policies $^{12}$, linked to the theoretical-methodological foundations of social occupational therapy.

\section{ETHICAL CONSIDERATIONS}

The original research on which this paper was based, was approved by Research and Ethics Committee of the Federal University of São Carlos (UFSCar), Brazil ${ }^{(2.761 .329)}$. and the discussion presented in this secondary analysis is covered by this approval.

\section{RESULTS AND DISCUSSION}

The original doctoral research generated results about the mobility restriction of the young favela dwellers. In the discussion of this research, it transpired that, these restrictions occur mainly because of the stigma attached to favela residents such as the per-

'Fanzine, a term formed from the combination of the words fan and magazine or zine, is an amateur, alternative, usually handcrafted, short-run printing publication. Due to these characteristics, fanzines are uncensored publications where it is possible to experiment with new aesthetics and language ${ }^{52}$. This resource has already been used by social occupational therapy in interventions with young people, as in Lopes, Borba and Monzeli53. 


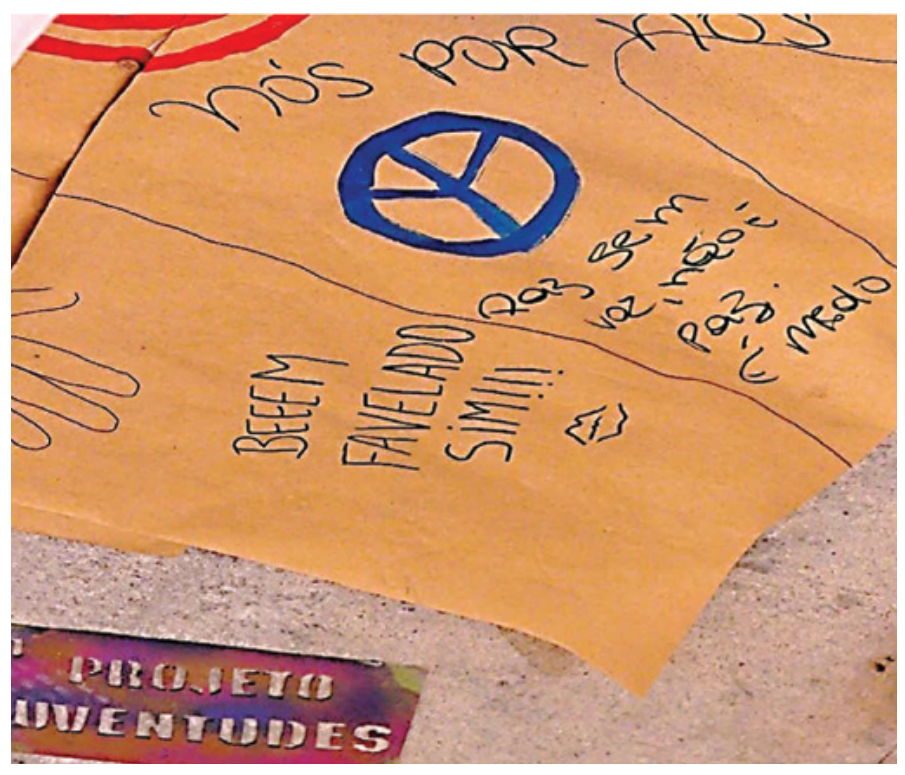

Figure 2: Detail of the body map with emphasis on the phrases: "We for us", "Real favela dweller indeed", and "Peace with no voice is not peace, it's fear". The phrases are written on the legs of the body map.

ception that links poverty to criminality and/or disorder. Fear of the unknown and of violence, in addition to sexuality and gender identity, associated with a favela dweller, influence the possibilities of and restrictions to urban mobility of those youngsters. Due to symbolic and concrete aspects, this restriction has an impact on the everyday lives of those young people, limiting their access to activities and, consequently, imposing a restriction to their cultural capital and social participation ${ }^{18}$.

Based on these conclusions, we present our reflections on how the concept of urban mobility can be used specifically in social occupational therapy practices. We use examples from the two research studies as they apply to professional practice, and in this paper, to actions through the university extension projects.

\section{Urban mobility as an objective of social occupational therapy}

As previously explained, when social participation is a difficult goal to be achieved, as in the case of most impoverished young favela dwellers, EUM can be an objective in intervention projects, since it forms the basis for the right to the city and for social participation $^{32-34}$.

A socio-historical-cultural understanding of the context should be considered so that urban mobility can be used as a guiding concept for the action objectives of social occupational therapy. In the case of this study, a socio-historical analysis of the favelas is essential to understand the mobility restriction of those youngsters. In the activity workshops, we worked with the group of young favela dwellers on the collective meanings they attach to their territory and other unknown territories where they want to go or have access to. During the workshops, the participants constructed a "City of Youth", aimed at establishing what those youngsters thought an "ideal" place for them would be and what type of spaces they would like to visit. In this process of collective construction, they spoke of the need for jobs, reported that their city "would not need a police station", mentioned that "favela dwellers are disorderly people", thus presenting a set of elements that allowed us to understand and discuss their territory ${ }^{21}$.

Using the activity workshops, participants reflected on where they are and how that place occupies the city, as well as on strategies for expanding their mobility. These reflections made it possible to configure the social occupational therapy actions needed in that location. Through the workshops, close bonds with the participants were developed, and this enabled an individual territorial followup through one-on-one discussions with individuals about mobility and ways of making it more effective in their everyday lives. Being together and visiting places together should be one of the professional strategies in social occupational therapy

It is also possible to objectify and implement actions related to resources in the social field and to stimulate the formal and informal dynamics of the support network to bring about the expansion of urban mobility. The stories of some of the youngsters that participated in the research showed how inclusion in the education network, for instance, can significantly increase their mobility, that is, access to education also enables the right to the city. In another situation, the story narrated by Elza, one of the youngsters who participated in the research, showed that the lack of coordination between health, education and social assistance services limited her access to the support she needed and, consequently, restricted her mobility.

Thus, through different social occupational therapy tools, expanding mobility should become an objective of professional action.

\section{Mobility as an assessment tool}

Assessments and assessment instruments are highly valued in the professional and research practices of occupational therapists. Rocha and Brunello ${ }^{35}$ claimed that the expansion of occupational therapy interventions and fields of action also leads to a necessity to rethink the assessments done by professionals, which should determine the needs, desires and cultural context of the individual, group, or community. According to Galheigo ${ }^{36}$ the development of an occupational therapy critical praxis depends on an approach that considers the historical context of the individual and their participant inclusion in the group.

In this sense, during the research, we conducted a mapping of places in the city that the young participants had visited, as well as of those places that were part of their everyday life. We started with a map of their neighbourhood and then moved on to a map of the city of Rio de Janeiro. We began by identifying their neighbourhood and then suggested that they localize on the map other neighbourhoods they had visited. After that, we asked them what they had done in each of those places, how they had gotten there, and how they had felt. This activity was carried out with four youngsters. These maps allowed us to understand and assess the concrete and symbolic aspects that have an impact on the urban mobility of these young people, as well as on other dimensions of their everyday lives, such as sociability, social participation, access to leisure and cultural devices and spaces, social rights, the violence suffered, among others.

Through these maps, we were able to learn how they moved about and understood the city. For example, one youngster claimed he had no difficulties with his urban mobility, but when he identified the places he used to visit, we found that his everyday life was limited to the favela where he lived. In contrast, two other young people reported, as they identified places on the map, that the expansion of their mobility occurred as a result of their inclusion in the education system, as the school "introduced" them to new and different places in the city. From the stories that unfolded during the activity with the maps, we found that it was a resource that contributed to explaining elements that possibly we would not have been able to 
Table I: Data collection synthesis.

\begin{tabular}{|c|c|c|c|}
\hline Method & Strategy & Activity & Participants $^{d}$ \\
\hline \multirow{9}{*}{ Workshops } & Workshop I & Presentations & Nara, Erasmo, Chico, Caetano, Gal, Vinicius, Rita \\
\hline & Workshop 2 & \multirow{4}{*}{ City of Youth } & Chico, Vinicius, Geraldo, Tom, Caetano, Rita, Milton \\
\hline & Workshop 3 & & Chico, Geraldo, Tom, Caetano \\
\hline & Workshop 4 & & Caetano, Chico \\
\hline & Workshop 5 & & Caetano, Erasmo \\
\hline & Workshop 6 & \multirow{3}{*}{ Manga } & Chico, Geraldo, João, Elza, Elis, Edu, Raul \\
\hline & Workshop 7 & & Noel, Elza, Geraldo, Edu, Chico, Elis, Luiz \\
\hline & Workshop 8 & & Elza, Geraldo, Caetano. \\
\hline & Public event & Youth and Human Rights & Open workshop conducted in the street \\
\hline \multirow{12}{*}{$\begin{array}{l}\text { Individual territorial } \\
\text { follow-ups }\end{array}$} & Meeting I & $\begin{array}{l}\text { A tour of the favela complex and a } \\
\text { virtual exhibition of photographs }\end{array}$ & Chico \\
\hline & Meeting 2 & $\begin{array}{l}\text { Production of a manga containing } \\
\text { the places he had visited in the } \\
\text { favela complex and the city }\end{array}$ & \multirow{4}{*}{ Chico } \\
\hline & Meeting 3 & \multirow{3}{*}{$\begin{array}{l}\text { Narratives based on the } \\
\text { photographs }\end{array}$} & \\
\hline & Meeting 4 & & \\
\hline & Meeting 5 & & \\
\hline & Meeting I & \multirow{2}{*}{$\begin{array}{l}\text { Conversation and a proposal to } \\
\text { build a Mobility Diary }\end{array}$} & \multirow{4}{*}{ Caetano } \\
\hline & Meeting 2 & & \\
\hline & Meeting 3 & A talk & \\
\hline & Meeting 4 & Preparation of a newspaper & \\
\hline & Meeting I & $\begin{array}{l}\text { Production of a manga containing } \\
\text { the places she had visited in the } \\
\text { favela complex and the city }\end{array}$ & Elza \\
\hline & Meeting I & $\begin{array}{l}\text { Production of a manga containing } \\
\text { the places he had visited in the } \\
\text { favela complex and the city }\end{array}$ & \multirow[t]{2}{*}{ Gil } \\
\hline & Meeting 2 & Conversation & \\
\hline
\end{tabular}

understand "only" through verbal discourse. Figure I (p34) shows one of the maps used during the activity.

Other resources used in the group activities, such as constructing a "City of Youth" 21 , preparing a collective map, enabled an understanding of how those youngsters understood the city, how they saw themselves and wanted to be seen, how they identified or not with that territory and with others, as well as their mobility between them. In other words, the use of activities to assess the mobility and the place of those young people in the city so that, based on this understanding, objectives for occupational therapy action can be outlined.

The construction of the body map is an example of a situation where resources are used to understand the mobility of those young people. Body mapping is a technique that consists in creating a life-size human body image from the outline of a body, where the participants intervene through reflections and feelings using various plastic and art materials available ${ }^{37,38}$. At different times, the young participants said they want to be seen as of "young favela dwellers", seeking to reframe the social image about favelas, which is permeated with stigmas. One of the phrases written was "Real favela dweller indeed". They spoke proudly about the favela, while referring to the limited access to some opportunities, resulting from social prejudice and lack of freedom of movement due to the violence experienced there: "we haven't got much access [to opportunities and spaces]; freedom of movement is important". A female youngster reported: "we have neither freedom nor peace to come and go". In this discussion, they mainly pointed out the stigmas of being a young favela dweller and the relationships with their skin colour, gender identity, and sexual orientation, as well as how these aspects have an influence on the restriction of their mobility and their participation in other spaces in the city. Figure 2 (p35) shows an example of one of the body maps created during the activities.

The examples of these activities are used as resources for understanding the mobility of those young people, which generate information, and as such, may be used as an assessment tool. However, we emphasize that this division into possible uses of the concept of urban mobility was designed with didactic purposes, and these dimensions are intertwined in practice ${ }^{12}$.

'All participants' names were replaced by fictitious names chosen by the researcher. 


\section{Urban mobility as a resource for practice}

Mobility as a resource refers to its use as a means to achieve the goal of occupational therapy intervention. Although EUM was not used specifically as a resource throughout the course of the research, it is possible to predict that moving together with the individuals, riding around on buses, participating in public spaces, planning routes and means of transportation, and accessing new places are actions that employ the concept of urban mobility as a professional action resource, as illustrated in the experience of Borba et al. ${ }^{39}$. These actions may be present in a more individualized dimension of the work, as well as in the activity workshops and individual territorial follow-ups, in the planning and execution of a tour of the city, or in participation in a cultural or political event.

Using EUM as a resource for professional action can be a way to expand social support networks and access to social policies, which is essential for the social participation ${ }^{8,10}$ and mobility of individuals, groups, and even communities. This possibility of using urban mobility as a resource of professional practice occurs through "going together" to spaces and developing individual and collective activities throughout the city, together with an existing group or incorporating new collectives. It includes information about the possibilities of places to be frequented, ways of access, routes, and the necessary and/or chosen/desired movemnets ${ }^{12}$.

\section{Urban mobility in social policies}

The involvement and participation of occupational therapists in social policies have been recurrently reported in the scientific literature: "Considering that occupational therapists are professionals who work in this society, seeking means to facilitate the social inclusion of people, participation in public spaces to determine those needs is required. Facing up to social inequality is imperative because it is mainly through public policies that occupational therapists can act in the everyday lives of people to foster social participation and inclusion"8:62.

Various studies have addressed the importance of occupational therapists' participation in proposing public policies for urban planning, and verified the small participation of these professionals at this level of politics ${ }^{11,40-45}$. One of the aspects highlighted in the these studies is that the occupational therapists' understanding of the individuals and collectives' everyday lives allows their participation in the construction of public policies to be contextualized within their reality and be meaningful to their everyday life.

Galheigo ${ }^{46}$ emphasizes the relevance of addressing everyday life, especially that of marginalized groups, aiming to reduce social invisibility. This strategy has been successful in processes of social oppression, strongly affecting the population followed up through social occupational therapy actions.

In the case of the city of Rio de Janeiro, where the research was conducted, knowledge of the everyday life in favelas is essential to propose policies that are in line with the local reality and needs, so that opportunities for the population of those territories can be expanded ${ }^{47-50}$. The research findings and the secondary analyses of these findings can assist occupational therapists in seeking subsidies to consolidate their participation in urban policies created for the most vulnerable populations in the city.

However, the effective participation of occupational therapists in the macro-social sphere of social policies is an important point as the individual territorial follow-ups of two young participants (Chico and Gil), demonstrated, for instance, how important education policies were in expanding their daily urban mobility and, consequently, their possibilities for social participation.

Caetano personifies this relationship, because from the moment he got into university - through the quota policies on access to higher education - he significantly increased his mobility. Since admission, more and more places have become no longer "unknown" and, in addition to becoming known territories, they have also become part of his everyday daily life ${ }^{22}$.

Although he still reports some issues such as being stared at when visiting different territories, he started circulating more broadly in the city of Rio de Janeiro. For instance, the city centre, where he had never been before, had become a place he often goes to visit museums and exhibits or to participate in demonstrations and events. He had also begun to go to the beach more often, both with his friends from the favela and with his new friends from college. It is important to highlight that Rio de Janeiro is the most famous coastal city in the country and he did not feel comfortable going to the beach before he started his university studies. In addition, he started using the subway comfortably (although not often, for financial reasons), which previously made him insecure because he was unfamiliar with this mode of transport.

Gil, 16 years old, also had his urban mobility expanded through access to education policies, in his case to secondary school. The access to a differentiated public secondary school associated with vocational education expanded his perception of the city and his cultural capital. As a result of this inclusion, unlike other young people, he began to use the subway daily, which expanded his access options to the city. The possibility of using different means of transport is also a factor that has an impact on urban mobility 3 and, in his case, it was the school that provided him with a new means of transport that is not culturally used by the residents of the favela where he lives, which allowed him to have access to other parts of the city.

Therefore, based on these narratives, we postulate that, occupational therapists could become be better informed about the everyday lives of these young people. However, to this end, it would be necessary for occupational therapists to assume a more political role as part of their professional practice, to contribute to the planning of social policies, including urban planning policies.

The assumption of this advocacy role however, rarely occurs. Few occupational therapists are effectively involved in framing social policies. One of the possible reasons for this situation is that most curricula are still focussed primarily on a biomedical and clinical perspective $^{51}$. Political participation is seldom addressed in education and is consequently not understood as a dimension of occupational therapy. It must be noted however, that in the university extension programmes in Brazil, social policies are becoming an integral part of the interactions with the population in which they occur, and as a consequence, are becoming part of other places of employment of occupational therapists

Social occupational therapy therefore encompasses the political dimension of the work of occupational therapists in two spheres 16: The macro-social sphere, which involves planning policies and service networks, and the micro-social sphere, where the direct involvement with individuals and collectives, leads to the constitution of forums and formal pathways to convey public demands.

\section{CONCLUSION}

Social occupational therapy action is ranges from local practices at the micro-social level to those at the macro-social level through engagement in actions that seek socio-structural changes to enable the social participation of socially vulnerable individuals and collectives. For these changes to occur at the macro-social level, there is need to acknowledge the political dimension in the work 
of occupational therapists, which can be expressed in advocating for their inclusion in the planning, implementation and participation in social policies. We also need to add a political perspective to the understanding and action in the everyday lives of the people we work with.

Social occupational therapy, from a political perspective of EUM, and employing its previously known resources and technologies (workshops/activities, dynamics and projects; individual territorial follow-ups; articulation of resources in the social field; dynamization of the support network ${ }^{16}$ ), can develop actions for urban mobility with the possibility of applying mobility as an objective, a resource, a means of assessing everyday life, and/or an aspect to be considered in micro- and macro-social work linked to social policies. This concept can be used as a subsidiary of professional practice.

Urban mobility restriction is a reality for socially vulnerable populations, such as the young favela dwellers who participated in the university extension project and the research on which this secondary analysis was based. These restrictions occur because of both symbolic and concrete aspects and have an impact on the everyday lives of these people. Consequently, their repertoire of accessible activities is restricted, which translates into limited social participation, especially at the macro-social level. In this context of restriction, social policies gain prominence even though they do not ensure urban mobility, as they do not change the social economic structure, which is fundamentally responsible for the restrictions experienced. However, these policies enable expansion of cultural and educational capital, which can also lead to expansion of urban mobility and, perhaps, of social participation.

\section{LIMITATIONS AND STRENGTHS}

Limitations of this study include the fact that it was carried out with a specific and local population participating in a university project in partnership with a NGO in the favela. Because this was a university extension project, occupational therapists have greater flexibility to think and develop their practices, without having to respond to institutional service dynamics. However, despite these considerations, based on critical analyses of participatory experiences, we understand that the report presented here can provide insights into the reality of social actions.

Articulating the concept of EUM with a foundation and interventions in social occupational therapy in search of contextualized and socially responsive academic actions, this study advocates that a political reading of the different dimensions of actions also contributes to the micro-social sphere of the individuals' lives. To this end, professionals can use occupational therapy resources with a view to expanding the possibilities for all.

\section{RECOMMENDATIONS}

Moving about together with the individuals; mapping the visited territories; enabling recognition of other territories; creating opportunities through social action; articulating public policies and territorial services and listening to their narratives about the meanings of the territory and urban mobility are social occupational therapy actions - notably from their focus on everyday life. This study was conducted with young favela dwellers, and it is recommended that this kind of research be extended to other communities we work with.

Seeking contextualized academic actions that are responsive to social demands is one of the functions of engaged knowledge production, and this should be on the academic agenda of the occupational therapy area.

\section{REFERENCES}

I. Lopes RE, Malfitano APS. Social Occupational Therapy - Theoretical and Practical Designs. Lopes RE, Malfitano APS, editors. Elsevier; 2021.

2. Barbosa JL. O significado da mobilidade na construção democrática da cidade [The meaning of mobility in the democratic construction of the city]. In: Balbim R, Krause C, Linke CC, editors. Cidade e Movimento. Mobilidades e Interações no Desenvolvimento Urbano [City and movement. Mobilities and interactions in urban development]. Brasília: Ipea: ITPD; 2016. p. 43-56.

https://www.ipea.gov.br/portal/images/stories/PDFs/livros/livros/160905_livro_cidade_movimento.pdf

3. Balbim R. Mobilidade: uma abordagem sistêmica [Mobility: A systemic approach]. In: Balbim R, Krause C, Linke CC, editors. Cidade e Movimento. Mobilidades e Interações no Desenvolvimento Urbano [City and movement. Mobilities and interactions in urban development]. Brasília: Ipea: ITPD; 2016. p. 23-42.

https://www.ipea.gov.br/portal/images/stories/PDFs/livros/livros/160905_livro_cidade_movimento.pdf

4. Savegnago SDO. Oportunidades de vida: fortuidades do tempo e mobilidades no espaço de jovens pobres cariocas. [Life opportunities: Fortunes of time and mobility in the space of poor young people from Rio de Janeiro]. Thesis (PhD in Psychology) - Institute of Psychology, Federal Univestity of Rio de Janeiro, Rio de Janeiro); 2018. http://www.nipiac.ufrj.br/producao2/item/778-oportunidades-devida-fortuidades-do-tempo-e-mobilidades-no-espa\%C3\%A7ode-jovens-pobres-cariocas.

5. Adey P. If Mobility is Everything Then it is Nothing: Towards a Relational Politics of (Im)mobilities. Mobilities. 2006 Mar; I ( I):75-94. https://doi.org// 0.1080/17450100500489080

6. Souza ASB. Presos no círculo, prostrados no asfalto: tensões entre o móvel e o imóvel [Trapped in circle, prostrate on asphalt: Tensions between furniture and property]. Thesis (PhD in Human Geography. Faculty of Philosophy, Letters and Human Sciences, University of São Paulo, São Paulo; 20I4. Available from:

https://teses.usp.br/teses/disponiveis/8/8136/tde-29092014152548/pt-br.php

7. Langevang T, Gough K V. Surviving through movement: the mobility of urban youth in Ghana. Soc Cult Geogr. 2009;10(7):74I-56. https://doi.org//0.1080/14649360903205 II6

8. Malfitano APS. Social Context and Social Action: Generalizations and Specificities in Occupational Therapy. In: Lopes RE, Malfitano APS, editors. Social Occupational Therapy- Theoretical and Practical Designs. Elsevier; 2021, p.60-68.

9. Barros DD, Ghirardi MIG, Lopes RE. Terapia ocupacional social [Social Occupational Therapy]. Rev Ter Ocup da Univ São Paulo. 2002; 13(3):95-103. https://doi.org/10.1 1606/issn.2238-6149.v13i3p95-103

10. Silva ACC da, Oliver FC. Social participation in occupational therapy: what are we talking about? Brazilian J Occup Ther. 2019;27(4):85872. https://doi.org//0.4322/2526-8910.ctoar I883.

II. Correia RL, Costa SL, Akerman M. Processos de inclusão e participação quilombola nas políticas urbanas na cidade [Quilombola inclusion and participation processes in the city urban policies]. Interinstitucional Brazilian J Occup Ther. 2018;2(4):827-39. https://doi.org// 0.47222/2526-3544.rbtol 4833

12. Gonçalves MV, Malfitano APS. The concept of urban mobility: articulating actions in occupational therapy. Brazilian J Occup Ther. 202 I; 29: e2523. https://doi.org/I0.1590/2526-89/0.ctoARFI929.

13. Gretschel P, Ramugondo EL, Galvaan R. An introduction to Cultural Historical Activity Theory as a theoretical lens for understanding 
how occupational therapists design interventions for persons living in low-income conditions in South Africa. South African J Occup Ther. 20I5;45(I):5I-5.

http://dx.doi.org/10.17/59/2310-3833/2015/v45nola9

14. Freire $P$. Cartas à Guiné-Bissau: Registros de uma experiência em processo [Pedagogy in Process: The Letters to Guinea-Bissau]. Rio De Janeiro: Paz e Terra; 1978. 173 p. https://cpers.com.br/wpcontent/uploads/2019/09/4.-Cartas-à-Guiné-Bissau.pdf

15. Freire P. Ação cultural para a liberdade e outros escritos [Cultural Action for Freedom]. Rio De Janeiro: Paz e Terra; 198I. 149 p. http://forumeja.org.br/files/Acao_Cultural_para_a_Liberdade.pdf

16. Lopes RE, Malfitano APS, Silva CR, Borba PL de O. Resources and Technologies in Social Occupational Therapy: Actions with Poor Urban Youth. In: Lopes RE, Malfitano APS, editors. Social Occupational Therapy- Theoretical and Practical Designs. Elsevier; 2021. p. 169-76.

17. Silva CR. Oficinas [Workshops]. In: Park MB, Fernandes RS, Carnicel $A$, editors. Palavras-chave da educação não formal [Keywords of non-formal education]. Holambra: Editora Setembro/Centro de Memória da Unicamp; 2007. p. 213-4.

18. Gonçalves MV. A mobilidade urbana de jovens em projeto social do Complexo do Alemão, no Rio de Janeiro, e suas relações com a terapia ocupacional social [Urban mobility of young people in a social project at Complexo do Alemão, in Rio de Janeiro, and its relationship with social occupational therapy]. Thesis (PhD in Occupational Therapy). Federal University of São Carlos; 2020. https://repositorio.ufscar.br/handle/ufscar//236I

19. Freire P. Extensão ou comunicação? [Extension or communication?]. Rio de Janeiro: Paz e Terra; 2013. 89 p.

20. Mello AF, Almeida Filho N, Ribeiro RJ. Por uma universidade socialmente relevante [For a socially relevant university]. Atos Pesqui e Educ. 2009;4(3):292-302. http://portal.mec.gov.br/dmdocuments/ cne_alexfiuza.pdf

21. Gonçalves MV, Malfitano APS. Brazilian youth experiencing poverty: Everyday life in the favela. J Occup Sci. 2020 Jul 2;27(3):3 I I-26. https://doi.org// 0.1080/14427591.2020.1757495

22. Gonçalves MV, Bezerra Neto LR, Malfitano APS. O cotidiano revelado por imagens da cidade [Everyday life revealed through images of the city]. Interface - Comun Saúde, Educ. 2020;24:I-14. https://doi.org/10.1590/interface. 190418

23. Lopes RE, Borba PLO, Trajber NKA, Silva CR, Cuel BT. Oficinas de atividades com jovens da escola pública: tecnologias sociais entre educação e terapia ocupacional [Activities workshops with public school youngsters: social technologies between education and occupational therapy]. Interface - Comun Saúde, Educ. 20I I; I5(36):27788. https://doi.org//0.1590/SI4I4-3283201 100010002I

24. Galheigo SM. Narrativas contemporâneas: significado, diversidade e contexto [Contemporary narratives: meaning, diversity and context]. Rev Ter Ocup da Univ São Paulo. 2009; 20(I):8-12. Available from: http://www.revistas.usp.br/rto/article/viewFile//4050/I5868

25. Ferreira VS. Caminhos e desafios metodológicos na pesquisa com jovens [Paths and methodological challenges in research with young people]. In: Vianna ACF, editor. Pesquisar Jovens - Caminhos e desafios metodológicos [Search for Young Paths and Methodological Challenges]. Lisboa: ICS. Impresa de Ciências Sociais; 20I 7. p. I7-32.

26. Frigotto $\mathrm{G}$. $O$ enfoque da dialética materialista histórica na pesquisa educacional [The focus of historical materialist dialectics in educational research]. In: Fazenda I, editor. Metodologia da pesquisa educacional [Educational research methodology]. 6a ed. São Paulo: Cortez; 2000. p. 69-90

27. Bourdieu P, Wacquant LJD. An Invitation to Reflexive Sociology.
Chicago: University of Chicago Press; 1992. 348 p.

28. Farias L, Rudman DL. Challenges in enacting occupation-based social transformative practices: A critical dialogical study. Can J Occup Ther. 2019 Jun 25;86(3):243-52. https://doi.org/10.1 177/0008417419828798

29. Farias L, Rudman DL. Practice analysis: Critical reflexivity on discourses constraining socially transformative occupational therapy practices. British J Occup Ther. 2019 Nov 15;82(1 I):693-7. https://doi.org/10.1 I77/03080226198621 I I

30. Richards L-A, Galvaan R. Developing a socially transformative focus in Occupational Therapy: insights from South African practice. South African J Occup Ther. 2018;48(I):3-8. http://dx.doi.org//0.17/59/2310-3833/2017/vol48nla2

31. Davidson E, Edwards R, Jamieson L, Weller S. Big data, qualitative style: a breadth-and-depth method for working with large amounts of secondary qualitative data. Qual Quant. 2019 Jan 26;53(I):36376. https://doi.org/I0.1007/s I I I35-0 I8-0757-y

32. Florentino R. Como transformar o direito à mobilidade urbana em indicadores de políticas públicas. [Uma contribuição How to turn the right to mobility in indicators of public policy? A contribution]. E-metropolis. 20I I;2(7):44-56. http://emetropolis.net/ artigo/50?name $=$ como-transformar-o-direito-a-mobilidade-emindicadores-de-politicas-publicas-uma-contribuicao

33. Movimento Passe Livre. Apresentação - Movimento Passe Livre/São Paulo [Presentation - Free pass movement/São Paulo]. Website. Available from: https://saopaulo.mpl.org.br/apresentacao/. (20 Feb 2019)

34. Pero V, Mihessen V. Mobilidade Urbana e Pobreza no Rio de Janeiro [Urban Mobility and Poverty in Rio de Janeiro]. Econômica. 20I3; I 5(2):23-50. https://doi.org/ I0.22409/economica. I5i2.p7 I

35. Rocha EF, Brunello MIB. Avaliação qualitativa em Terapia Ocupacional: Princípios, métodos e técnicas de coleta de dados [Qualitative assessment in Occupational Therapy: Principles, methods and techniques of data collection]. In: Cavalcanti A, Galvão C, editors. Terapia Ocupacional - Fundamentação e Prática [Occupational Therapy - Foundation and Practices]. Rio de Janeiro: Guanabara Koogan; 2007. p. 44-8.

36. Galheigo SM. Occupational therapy, everyday life and the fabric of life: theoretical-conceptual contributions for the construction of critical and emancipatory perspectives. Brazilian J Occup Ther. 2020;28(I):5-25. Available from: http://www.scielo.br/scielo. php?script $=$ sci_arttext\&pid $=$ S2526-89 $102020005004203 \& \operatorname{lng}=e$ n\&nrm $=$ iso\&tlng $=$ en

37. Davy C, Magalhães LV, Mandich A, Galheigo SM. Aspects of the resilience and settlement of refugee youth: a narrative study using body maps. Cad Ter Ocup da UFSCar. 2014;22(2):23I-4I. https://doi.org/10.4322/cto.2014.045

38. Gastaldo D, Magalhães L, Carrasco C, Davy C. Body-Map Storytelling as Research: Methodological considerations for telling the stories of undocumented workers through body mapping. Ontario: Creative Commons; 2012. 51 p. http://www.migrationhealth.ca/ sites/default/files/Body-map_storytelling_as_reseach_HQ.pdf

39. Borba PLO, Costa SL, Savani ACC, Anastácio CC, Ota NH. Entre fluxos, pessoas e territórios: delineando a inserção do terapeuta ocupacional no Sistema Único de Assistência Social [Between flows, people and territories: outlining the insert of occupational therapist in the Brazilian Social Assistence System]. Cad Ter Ocup da UFSCar. 2017;25(I):203-14. https://doi.org/10.4322/0 I04-4931.ctoRE0758

40. Correia RL, Costa SL, Akerman M. Processos de ensinagem em desenvolvimento local participativo [Teaching-learning in the participatory local development]. Interações; |8(3):23. https://doi.org/10.20435/inter.v18i3.1526 
4I. Correia RL, Vieira Filho PR, Gomes EM de B, Costa CCC, Paulino CT da S. Terapia Ocupacional no planejamento urbano das cidades [Occupational Therapy in urban planning of cities]. Anais do XII Congresso Norte - Nordeste de Terapia Ocupacional "Identidade da Terapia Ocupacional no Brasil: reflexões, desafios e perspectivas" [Annals of XII North-Northeast Occupational Therapy Congress: "Identity of Occupational Therapy in Brazil: reflexions, challenges andperspectives”] Interinstitucional Brazilian J Occup Ther. 2018;356. Available from:

https://revistas.ufrj.br/index.php/ribto/article/view/20353/pdf

42. Di Stefano M, Stuckey R, Lovell R. Promotion of safe community mobility: Challenges and opportunities for occupational therapy practice. Aust Occup Ther J. 2012;59(I):98-102. https://doi.org/10.1 I I I/j.1440-1630.201 I.00993.x

43. Jónasdóttir SK, Egilson SP, Polgar J. Services, systems, and policies affecting community mobility for people with mobility impairments in Northern Iceland: An occupational perspective. J Occup Sci. 2018; I-13. https://doi.org/10.1080/1442759I.2018.1474797

44. Jónasdóttir SK, Polgar JM. Services, systems, and policies affecting mobility device users' community mobility: A scoping review. Can J Occup Ther. 2018;85(2):106-16. https://doi.org//0.1177/0008417417733273

45. Parnell T, Wilding C. Where can an occupation-focussed philosophy take occupational therapy? Aust Occup Ther J. 2010;57(5):345-8. https://doi.org/10.1 I II/j.1440-1630.2010.00860.x

46. Galheigo SM. What needs to be done? Occupational therapy responsibilities and challenges regarding human rights. Aust Occup Ther J. 201 I;58(2):60-6. https://doi.org/10.1 I I I/j. I440-1630.201 I.00922.x

47. Leitão G. Reconhecendo a diversidade das favelas cariocas [Recognizing the diversity of Rio's favelas]. In: Silva JS, editor. O que é favela, afinal? [What is a favela after all]. Rio de Janeiro: Observatório de Favelas do Rio de Janeiro; 2009. p. 36-45. http://observatoriodefavelas.org.br/wp-content/uploads/2013/09/o-que-é-favela-afinal.pdf

48. Cavallieri F. Favelas no Rio - a importância da informação para as políticas públicas [Favelas in Rio - the importance of information for public policies]. In: Silva JS, editor O que é favela, afinal? [What is a favela after all]. Rio de Janeiro: Observatório de Favelas do Rio de Janeiro; 2009. p. 24-9. http://observatoriodefavelas.org.br/wpcontent/uploads/2013/09/o-que-é-favela-afinal.pdf

49. Observatório de Favelas. Declaração: o que é favela, afinal? [Declaration: What is a favela after all?] In: Silva JS, editor. O que é favela, afinal [What is a favela after all?] Rio de Janeiro: Observatório de Favelas do Rio de Janeiro; 2009. p. 96-7. http://observatoriodefavelas.org.br/wp-content/uploads/2013/09/o-que-é-favela-afinal.pdf

50. Silva JS. Um espaço em busca de seu lugar: as favelas para além dos estereótipos [A space in search of its place: Favelas beyond stereotypes]. In: Santos M, Becker BK, editors. Território, Territórios Ensaios sobre o ordenamento territorial [Territory, territories. Essays on land use planning]. 3rd ed., Rio de Janeiro: Lamparina; 2007. p. 209-30. https://docplayer.com.br/647/376-Um-espacoem-busca-de-seu-lugar-as-favelas-para-alem-dos.html

5I. Pan LC, Lopes RE. Políticas de ensino superior e a graduação em Terapia Ocupacional nas instituições federais de ensino superior no Brasil [[Higher education politics and the graduation in Occupational Therapy at the Federal Institutions of Higher Education in Brazil].]. Cad Ter Ocup da UFSCar. 2016;24(3):457-68. Available from: http://doi.editoracubo.com.br/10.4322/0104-4931.ctoAO0704

52. Magalhães $\mathrm{H}$. O que é fanzine [What is fanzine]. Ia. São Carlos: Brasiliense; 1993. $79 \mathrm{p}$.

53. Lopes RE, Borba PLO, Monzeli GA. Expressão livre de jovens por meio do fanzine: recursos para a terapia ocupacional social [Free expression of young people through Fanzine: resource for social occupational therapy]. Saúde e Soc. 2013 [cited 2019 May 10];22(3):937-48. Available from:

https://www.scielosp.org/pdf/sausoc/2013.v22n3/937-948/pt

Corresponding Author

* Monica Villaça Gonçalves

Email: movillaca@gmail.com 